\title{
News from IUGS National Adhering Bodies...
}

\section{- HUNGARY}

Professor G. Grasselly (IUGS Vice-President) reports that the Hungarian National Committee of IUGS is now headed by:

- Acad. E. Szádeczky-Kardoss (President)

- Dr. Peter Ottlik (Secretary)

\section{- ISRAEL}

Mrs. A. Hyam, Secretary-General of The Israel Academy of Sciences and Humanities, reports that the Israeli National Committee for IUGS is currently composed of the following members:

- Professor Z. Reiss (Chairman)

(Dept. of Palaeontology, The Hebrew University of Jerusalem)

- Professor R. Picard (The Israel Academy of Sciences and Humanities)

- Dr. G. Gwirtzman (Geological Survey of Israel)

. Dr. U. Kafri (Geological Survey of Israel)

. Dr. E. Zohar (Geological Survey of Israel)

\section{- NEW ZEALAND}

A.S. Chisholm, reporting for the Executive Officer of the Royal Society of New Zealand, notes that no changes have occurred in the membership of the New Zealand National Committee for Geological Sciences as a result of the 1979 elections. The Committee comprises:

Prof. J.A. Grant-Mackie (Chairman), Dr. L. Carter, Dr.
T.M. Hunt, Dr. A. Reay, Dr. R.P. Suggate, Mr. G. Warren, Dr. R.W. Bailey (International Secretary, ex officio)

\section{- PEOPLE'S REPUBLIC OF CHINA}

Former Secretary-General of the Geological Society of China, Meng Chi-sheng reports that at the 33rd Council Session of the Geological Society in March, the following elections took place in the Society:

. Prof. Huang Jiqing (T.K. Huang) - President

(Vice President, Chinese Academy of Geological Sciences)

. Mr. Wang Zejiu - Secretary-General

(Vice President, Chinese Academy of Geological Sciences)

\section{- SYRIAN ARAB REPUBLIC}

The Syrian Council of Ministers has issued a decree nominating the following as members of the National Council for Geology and Mineral Resources in the Syrian Arab Republic:

. Dr. H. Ibrahim (Chairman)

(Director, The General Establishment of Geology and Mineral Resources)

- Dr. M. Shaban Nagieb (Secretary)

(Senior Adviser to the Minister of Petroleum)

Mr. I. Jarmakani, Dr. M. Mouti, Dr. K. Maleh, Dr. M. Autaki 